\title{
EDUCAÇÃO E CIDADANIA: ALGUMAS HERESIAS
}

\author{
Mario Sergio CORTELLA
}

Um dos "dogmas"mais resistentes no interior da sociedade brasileira dos últimos 20 anos tem sido o da inexorável falência da Escola Pública e, por contraposição, a excelência da Escola Particular. Esse dogma costuma vir acompanhado de uma certa nostalgia em relação à Escola Pública do passado (paraíso perdido da qualidade) e da beatificação da Escola Particular do presente (morada alegre da salvação). No entanto, a crítica (herética?) é necessária; afinal, por que aceitar santamente o martírio nas chamas da inquisição neoliberal?

Por que estou iniciando por essa colocação? Porque a questão central não é a discussão entre Escola Pública X Escola Privada, mas é a escola boa versus a escola ruim. Há uma mitificação em torno da relação pública/privada, como se fossem antípodas no que se refere às condições de qualidade; boas e ruins as temos em ambos os campos. A discussão mais séria hoje no nosso pais deve ser sobre a universalização e a qualidade do ensino e, fundamentalmente, a formação de cidadania que a Escola deva estar propiciando a partir do trabalho com os educadores.

Há uma contradição forte em nosso país: somos a oitava máquina internacional de produção de riqueza no conjunto das 150 principais naçð̃es que, de uma certa forma, representam a existência de 5,3 bilhões de humanos neste planeta. Somos a oitava maior estrutura de geração de bens e serviços para a sustentação da vida humana; no entanto, de acordo com algumas classificações, somos a 56a. em Educação (penúltimos da América Latina!). Isso significa o grau de violência simbólica e efetiva existente em nossa organização social.

Não é necessário ser especialista em estatística para entender o nível dessa violência: dos 150 milhões de cidadãos brasileiros, 34 milhões estão freqüentando escolas, dos quais 30,5 milhões no 10. grau, 2,5 milhões no 20. e 1,0 milhão no 30.grau. O grau de "mortalidade estudantil" dentro do sistema é altíssimo; o percentual dos que cursam escolas além da Educação Fundamental é algo mais do que $10 \%$ dos matriculados na escolaridade básica! Ademais, em 1993 temos mais de 5 milhões de cidadãos em idade constitucionalmente obrigatória (sete a 14 anos) fora da escola, somando-se aos quase 40 milhões de analfabetos totais ou funcionais de nosso país.

Não podemos esquecer o analfabetismo de adultos! Muitos entre aqueles que hoje falam euforicamente sobre a pretensa universalização do Ensino Fundamental no Brasil, ou omitem deliberadamente a imensa massa de cidadãos adultos ainda analfabetos, ou, pior, defendem a não necessidade de investir recursos para alfabetizá-los. Não são poucos, entre educadores afamados, os que advogam a tese de que a saída para o analfabetismo adulto será dada pela própria natureza, ou seja, com a morte desses analfabetos. Esse elogio do "social/darwinismo" vem tomando corpo nos debates e nada mais significa do que um incremento do apartheid social já comum em outras áreas em nosso país. Ademais, a defesa dessa tese é, no mínimo, inconstitucional, à medida em que a Constituição Brasileira de 1988 estabelece a obrigatoriedade da erradicação do analfabetismo em um prazo de 10 anos de sua promulgação (já estamos na metade do prazo!) e é tão abstrusa quanto uma proposta de negação de acesso ao sistema de saúde para os doentes terminais ou idosos. $O$ acesso à escolarização de algum tipo é um direito de cidadania e esse debate já está superado, enquanto teoria, desde o século XVIII. A escolarização, mais do que um mero canal para absorção de conhecimentos (os quais, poder-se-ia argumentar, não são tão úteis mais para adultos idosos), é uma experiência sócio/cultural extremamente rica e, dela, não é justo excluir cidadãos sob qualquer pretexto.

\footnotetext{
- Pontificia Universidade Católica de São Paulo.
} 
Por que coloco esses dados? Porque por intermédio deles verifica-se o grau de cautela com que devem ser vistas as recentes pesquisas neo-liberais que tentam mostrar que houve universalização da educação básica. Há duas situaç̃es concretas (amenizadas na divulgação dessas pesquisas) que mascaram a pretensa universalização: não é incomum que um aluno evadido ou retido, ao matricular-se novamente (na mesma ou em outra escola), seja contado duas vezes pelo menos, pois as sistemáticas de controle nas escolas públicas (majoritárias) ainda são arcaicas; a outra situação é mais prosaica: se colocarmos, de um lado, o número total de crianças e adolescentes na faixa etária obrigatória e, de outro lado, o número de vagas existentes, veremos que, sem dúvida, um cabe dentro do outro mas, nem sempre as vagas e as crianças estão no mesmo lugar... Então é preciso cuidado na análise dessas pesquisas que conduzem a uma falsa euforia quanto à universalização e que acabam levando à conclusão de que não é preciso aumentar tanto os gastos com Educação.

O Brasil é, de fato, um dos países que, no registro orçamentário, mais investe em Educação; atualmente é mais de 3,5\% do PIB, uma taxa quase equivalente a dos países mais desenvolvidos. No entanto, há uma diferença entre orçamentário e financeiro (desembolso efetivo) pois temos desperdício, burocracia exagerada, corrupção, demora nos repasses etc, fazendo com que, em média de cada US\$100.00 orçamentários apenas US $\$ 20.00$ cheguem realmente à cada unidade escolar pública. E mais: nossos déficits educacionais são estruturais, de tal forma que o investimento não é suficiente; não podemos cair na armadilha de imaginar que temos recursos suficientes mas são apenas mal aplicados. Ou seja, não basta racionalizar a máquina administrativa, pois a insuficiência continuará se quisermos recuperar 0 atraso histórico.

Para muitos, esse atraso histórico tem como ponto de referência a escola pública de 50 ou menos anos atrás; há hoje uma "saudade" muito grande em relação à escola brasileira do passado e esse é outro dos mitos que carece de revisão.

De fato, a escola pública do passado detinha melhores condições de qualidade; no entanto, é preciso identificarmos quais eram os beneficiários dessa qualidade no conjunto dos cidadãos...

No início dos anos 60 , apenas $30 \%$ dos brasileiros viviam nas cidades e $70 \%$ na área rural; o modelo político/econômico implantado a partir de 1964 levou a uma migração interna acelerada e a uma urbanização inédita em nossa história. A maioria da nossa população, por falta de reforma agrária - 0 único grande país capitalista que não a fez até hoje - e em função do modelo econômico concentrador dos meios de produção, teve de imigrar para as cidades e, de 1964 até 1984, foi invertida a relação cidade/campo: em $1984,70 \%$ na cidade e $30 \%$ no campo. Hoje, de acordo com o último censo, a relação já é de $80 \%$ urbanos e $20 \%$ rurais!

Houve, portanto, um inchaço urbano extremamente veloz (a cidade de São Paulo, por exemplo, quase dobrou a sua população a cada dez anos). Conseqüência imediata? Um estouro da demanda por serviços públicos como educação, saúde, transporte, bem estar, habitação etc; esses serviços são pouco demandados na área rural, seja porque sua população vive desconcentradamente e tem menos condiç̋̋es de organização, seja porque, em termos de produção capitalista, sua atividade produtiva requisita um mínimo acesso aos códigos lingüísticos e matemáticos.

Ora, tudo isso "coincidiu" com a fase das menores taxas de investimento público em educação; no início dos anos 70 era $1,6 \%$ do PIB, resultando em quase nada face à demanda existente. A "democratização" do acesso à escola não foi acompanhada do investimento correspondente, os salários dos educadores foram sendo reduzidos, a formação docente massificada, as condições de trabalho depauperadas etc. A escola pública, quando foi se tornando, de fato, pública, perdeu qualidade e entrou em crise permanente. Tal como já se afirmou, a crise da Educação no Brasil não é uma crise, é um projeto das elites e, ainda continua em execução, gerando uma fabulosa estrutura de produção do fracasso escolar.

O fracasso escolar é alto em nosso país e, em grande parte, sua responsabilidade tem sido atribuída aos próprios alunos; já se oscilou entre "acusar" alunos ou professores mas a culpabilidade discente continua em voga. Não é incomum encontrarmos colegas docentes dizendo "os alunos de hoje não são mais os mesmos", o que é uma coisa óbvia; curioso é alguém constatar essa obviedade e continuar dando aulas do mesmo modo como dava há 15 ou 20 anos atrás... A área da Educação ainda é uma das poucas para a qual o fracasso do serviço incrimina o usuário; quando se fala em "fracasso hospitalar" dificilmente passaria pela cabeça de alguém responsabilizar os pacientes no lugar do Estado, dos profissionais, da estrutura, etc. 
Assim, soma-se ao problema da democratização do acesso a cada vez mais requisitada nova qualidade de ensino. Para isso, considero que o "meio tecnológico" mais avançado é o educador e o investimento em sua formação e condiçðes de trabalho.

Em suma, a Educação Brasileira tem problemas profundos; eles não serão resolvidos nem pelos dogmas do maniqueísmo mercantil e nem pela disfarçada delinqüência estatal.

Concluindo, penso ser urgente um movimento nacional em torno da Educação tal como foi, em nossa história, o da Anistia, das Diretas-Já, o do "Impeachment"; é preciso transformar o discurso ideológico em defesa da Educação (cínico, da parte de alguns) em ação política organizada. Sem um envolvimento dos educadores (públicos e privados), esse movimento não ocorrerá. Não é uma bandeira corporativa e sim, um ato de cidadania decente. 